\title{
Physical-mechanical properties of panels produced with corn cob particles and different types and contents of adhesives
}

\author{
Propriedades físico-mecânicas de painéis produzidos com partículas de sabugo de millho e \\ diferentes tipos e teores de adesivos \\ Propiedades físico-mecánicas de paneles producidos con partículas de mazorca de maíz y diferentes
} tipos y contenidos de adhesivos

Received: 08/25/2021 | Reviewed: 09/03/2021 | Accept: 09/07/2021 | Published: 09/09/2021

\author{
Marina Resende Ribeiro de Oliveira \\ ORCID: https://orcid.org/0000-0003-3425-3885 \\ Universidade Federal de Lavras, Brasil \\ mari.rroliveira@gmail.com \\ Flávia Maria Silva Brito \\ ORCID: https://orcid.org/0000-0002-6834-8666 \\ Universidade de São Paulo, Brasil \\ E-mail: faengflorestal@gmail.com \\ Luciana Silva Villela \\ ORCID: https://orcid.org/0000-0002-9246-9476 \\ Universidade Federal de Lavras, Brasil \\ E-mail: lucianavillela_3@hotmail.com \\ Lourival Marin Mendes \\ ORCID: https://orcid.org/0000-0001-8713-405X \\ Universidade Federal de Lavras, Brasil \\ E-mail: lourival@ufla.br \\ José Benedito Guimarães Júnior \\ ORCID: https://orcid.org/0000-0002-9066-1069 \\ Universidade Federal de Lavras, Brasil \\ E-mail: jose.guimaraes@ufla.br
}

\begin{abstract}
The objective of this research was to evaluate the best type and adequate content of adhesive in low density particleboards produced with corn cob, in addition to the chemical analysis of the particles. The adhesives used were urea-formaldehyde (UF) and phenol-formaldehyde (PF) distributed in three levels $(6,9$ and $12 \%)$ on the dry mass of the particles and the nominal density was $0.60 \mathrm{~g} . \mathrm{cm}^{-3}$. Regarding the water absorption and swelling properties, no significant differences were found between treatments. The mean value calculated for the IE $24 \mathrm{~h}$ was $37.07 \%$, being above the minimum limit stipulated by the standard. The modulus of rupture (MOR) and modulus of elasticity (MOE), were influenced by the tested factors. All particleboards met the requirements of the standard norm. For internal adhesion there was a significant effect only for the type of adhesive factor, with the particleboards produced with PF showing the highest means. For the compression property there was no effect of the factors tested. In general, the dimensional stability of the particleboards was below the minimum required by the standard, but the mechanical properties met all requirements.
\end{abstract}

Keywords: Chemical analysis; Physical-mechanical properties; Waste.

\begin{abstract}
Resumo
O objetivo desta pesquisa foi avaliar o melhor tipo e teor adequado de adesivo em painéis aglomerados de baixa densidade produzidos com sabugo de milho, além da análise química das partículas. Os adesivos utilizados foram uréia-formaldeído (UF) e fenol-formaldeído (FF) distribuídos em três teores (6, 9 e 12\%) sobre a massa seca das partículas e a densidade nominal foi $0,60 \mathrm{~g} \cdot \mathrm{cm}^{-3}$. Em relação às propriedades de absorção de água e inchamento, não foram constatadas diferenças significativas entre os tratamentos. O valor médio calculado para o IE $24 \mathrm{~h}$ foi $37,07 \%$, acima do limite mínimo estipulado pela norma. O módulo de ruptura (MOR) e o módulo de elasticidade (MOE), foram influenciados pelos fatores testados. Todos os painéis aglomerados atenderam aos requisitos da norma padrão. Para a adesão interna houve efeito significativo apenas para o fator tipo de adesivo, sendo que os painéis produzidos com FF evidenciaram as maiores médias. Para a propriedade de compressão não houve efeito dos fatores testados. De forma geral, a estabilidade dimensional dos painéis ficou abaixo do mínimo requerido pela norma, mas as propriedades mecânicas atenderam a todos os requisitos.
\end{abstract}

Palavras-chave: Análise química; Propriedades fisico-mecânicas; Resíduos. 


\section{Resumen}

El objetivo de esta investigación fue evaluar el mejor tipo y contenido adecuado de adhesivo en tableros de particulas de baja densidad producidos con mazorca de maíz, además del análisis químico de las partículas. Los adhesivos utilizados fueron urea-formaldehído (UF) y fenol-formaldehído (FF) distribuidos en tres niveles (6, 9 y $12 \%)$ sobre la masa seca de las partículas y la densidad nominal fue de $0,60 \mathrm{~g} . \mathrm{cm}^{-3}$. En cuanto a las propiedades de absorción e hinchamiento de agua, no se encontraron diferencias significativas entre tratamientos. El valor medio calculado para IE $24 \mathrm{~h}$ fue del 37,07\%, por encima del límite mínimo estipulado por la norma. El módulo de ruptura (MOR) y el módulo de elasticidad (MOE) fueron influenciados por los factores probados. Todos los paneles de aglomerado cumplieron los requisitos de la norma estándar. Para la adherencia interna hubo un efecto significativo solo por el tipo de factor adhesivo, y los paneles producidos con FF mostraron los promedios más altos. Para la propiedad de compresión no hubo efecto de los factores probados. En general, la estabilidad dimensional de los paneles estuvo por debajo del mínimo requerido por la norma, pero las propiedades mecánicas cumplieron con todos los requisitos.

Palabras clave: Análisis químico; Propiedades físico-mecánicas; Residuos.

\section{Introduction}

Panels produced with wood particles, pressed with synthetic adhesives under heat and pressure, are called particleboards. For the production of particleboards in Brazil, the species of the genus Pinus and Eucalyptus from forest plantations are used (Iwakiri et al., 2019), but any material with chemical constitution similar to wood (cellulose, hemicellulose and lignin) can be used as raw material.

Research already carried out indicates the feasibility of using alternative materials for the production of particleboards, such as: sorghum residue, babassu coconut residues, corn cobs, rice husks, coffee husks, bamboo and sugar cane bagasse, among others. These experiments indicated that the materials can be promising in relation to sustainable production, low cost of raw material, in addition to adding substantial value, in the case of agro-industrial waste.

The Brazilian economy is largely supported by agribusiness. In 2019, agribusiness had a 21.4\% share in the Brazilian GDP, with $14.6 \%$ contribution from the agricultural sector and 6.8\% from the livestock sector (Centro de Estudos Avançados em Economia Aplicada - CEPEA and Confederação da Agricultura e Pecuária do Brasil - CNA, 2020). The high agricultural production results in large volumes of lignocellulosic residues, mostly from soy, coffee, sugar cane and corn. Among these, corn stands out, being cultivated in all regions of Brazil.

Agricultural and livestock regions in the country depend on corn for new revenue opportunities, reduction in production costs and, mainly, new business opportunities (Cortini et al., 2018). Estimates point to a record production of more than 108.068 thousand tons of corn in Brazil, for the month of March / 2021, with emphasis on the volume forecast in the second harvest, which represents almost $77 \%$ of this total (CONAB, 2021). For every $100 \mathrm{~kg}$ of corn cobs, $18 \mathrm{~kg}$ of cob are produced (Oliveira et al., 2020).

Therefore, it is an estimated value of 53.95 million tons of waste and, therefore, some options should be sought in order to provide an adequate use for this type of waste. One option is the use of cob as a raw material for the production of particleboards, since this waste is a lignocellulosic material. Some studies have already been carried out with particleboards made of corn cob particles, associated or not with other materials such as: Scatolino et al. (2013) and Silva et al. (2015).

In the particleboard industry, in addition to the raw material, the adhesive is another factor of great importance. Resins based on urea-formaldehyde and phenol-formaldehyde are the main types of synthetic thermoset adhesives used by the wood particleboard industries (Iwakiri et al., 2019).

Urea formaldehyde (UF) based adhesives have many advantages and are one of the most popular resins. Among the advantages are the low cost, the color and it is easy to work with, however it has low resistance to humidity. Phenolformaldehyde is the most used in the production of particleboards for structural purposes intended for the external environment, with or without protection, such as plywood and OSB (Iwakiri et al., 2019). The type of adhesive and the content used in the manufacture of the sheets depends on the type of product and its application. 
Considering the growing demand for raw materials by the particleboard sector and the scarcity of resources in some regions, there is a need to seek alternative sources that can be used by industries. Associated with this issue, it should be taken into account the quantities of agricultural waste generated daily and which can be used for the production of particleboards, adding value to them. Within this context the objective of this research was to evaluate the best type and adequate content of adhesive in low density particleboards produced with corn cob particles.

\section{Methodology}

\subsection{Obtaining the materials}

The raw material used in this work (corn cob) was obtained from cobs originated from experimental plantations grown in the city of Lavras-MG, Brazil. After collecting the cobs, the husks and grains were removed manually. Subsequently, the cobs were ground in a hammer mill to obtain the particles.

After grinding, the waste was classified in a vibrating set with three overlapping sieves, with openings of $1.410 \mathrm{~mm}$ (upper), $0.595 \mathrm{~mm}$ (intermediate) and $0.250 \mathrm{~mm}$ (lower). Coarse and fine particles were removed. For the production of the particleboards, the particles retained in the two sieves $(2.00$ and $0.595 \mathrm{~mm}$ ) were used. The particles were mixed properly, using a 1:1 ratio and homogenized in plastic bags. Subsequently, they were kept at $70{ }^{\circ} \mathrm{C}$ in an oven with forced air circulation until they reached $3 \%$ moisture in the dry base.

\subsection{Corn cob density and chemical components}

The basic density was carried out according to the guidelines of the Brazilian Regulatory Standard - NBR 11941 of the Brazilian Association of Technical Standards (ABNT, 2003) with some adaptations in measuring the volume, as described by Silva et al. (2015).

To determine the chemical components, an appropriate portion of particles was selected, which was transformed into sawdust using a Willey mill. Then, the material that passed through the 40 mesh sieve and was retained in the 60 mesh screen was selected. The analyzes were performed in triplicates. Total extractive content (Associação Brasileira Técnica de Celulose e Papel - ABTCP M 3/69, 1974), insoluble lignin content (ABTCP M 10/71, 1974), ash content (NBR 13999 - ABNT, 2003) were determined and the holocellulose content, obtained by difference, according to Eq. 1:

Holocellulose $(\%)=100-($ Total extractives + Lignin content + Ash $)(1)$

\subsection{Making the particleboards and obtaining the specimens}

The adhesive used was urea-formaldehyde (UF), with a solids content of $57.06 \%, \mathrm{pH}$ of 8.02 , viscosity of $485 \mathrm{cP}$ and gelatinization time of 47 seconds, according to the technical sheet provided by the company. The phenol-formaldehyde (PF) adhesive had a solids content of 50.87\%; $\mathrm{pH}$ of 12.45 ; viscosity of 595Cp and gelatinization time of $10.12 \mathrm{~min}$. The adhesives were applied separately on the particles in the amounts of $6 \%, 9 \%$ and $12 \%$ resinous solids, according to the treatment adopted, based on the mass of particles at $0 \%$ humidity. Three particleboards were produced for each treatment, totaling nine experimental units.

The adhesive was applied by spraying on a rotating drum type gluing machine. Then, the encased particles were deposited manually in a wooden box forming the mattress, with internal dimensions of $48 \times 48 \mathrm{~cm}$. The particle mattress was pre-pressed in a manual hydraulic press, for air removal and pre-consolidation, under pressure corresponding to $0.5 \mathrm{MPa}$, for $10 \mathrm{~min}$. 
Then, the mattress was hot pressed in a motorized press. The parameters of the pressing cycle were as follows: 4.0 MPa pressure, temperature of $160^{\circ} \mathrm{C}$ and the pressing time was $8 \mathrm{~min}$. Metal spacers were used so that the particleboards reached a thickness of $15 \mathrm{~mm}$ during pressing. Then, the particleboards were placed in an air-conditioned room with a temperature of $22 \pm 2^{\circ} \mathrm{C}$ and a relative humidity of $65 \pm 5 \%$ with temperature, until a constant mass was obtained.

The particleboards were squared in a circular saw, and $1.0 \mathrm{~cm}$ was removed from each end, to avoid the edge effect, and then specimens were removed to perform the physical and mechanical tests. Four specimens were removed per particleboard to evaluate the static bending test, carried out in accordance to the requirements of the Deutsches Institut Fur Normung - DIN 52362 (1982); six specimens per particleboard, for perpendicular traction and two specimens per particleboard, for water absorption and thickness swelling after $2 \mathrm{~h}$ and $24 \mathrm{~h}$ of immersion, according to the designations of the American Society for Testing and Materials - ASTM D 1037 (2020).

\subsection{Experimental design and statistical analysis of the data}

To evaluate the basic density and chemical constitution, an experimental descriptive statistical analysis was performed, with mean values and standard deviation.

The experimental design was completely randomized, with a $2 \times 3$ factorial arrangement for the treatments. Two factors were analyzed: two levels of adhesive (UF and PF) and three levels of adhesive (6, 9 and 12\%). Three particleboards were manufactured for each treatment, thus totaling 18 experimental units (Table 1).

Table 1. Experimental treatments performed.

\begin{tabular}{lll}
\hline Treatments & Types of adhesive & Adhesive contents \\
\hline T1 & Urea Formaldehyde (UF) & $6 \%$ \\
T2 & Urea Formaldehyde (UF) & $9 \%$ \\
T3 & Urea Formaldehyde (UF) & $12 \%$ \\
T4 & Phenol Formaldehyde (PF) & $6 \%$ \\
T5 & Phenol Formaldehyde (PF) & $9 \%$ \\
T6 & Phenol Formaldehyde (PF) & $12 \%$ \\
\hline
\end{tabular}

Source: Authors.

An analysis of variance (ANOVA) was carried out to evaluate the results of the treatments. In cases of rejection of the equality hypothesis, the tukey test was applied at $5 \%$ significance.

\section{Results and Discussion}

\subsection{Basic density and chemical components of corn cob}

The basic density obtained for the corn cob was $0.177 \pm 0.15 \mathrm{~g} . \mathrm{cm}^{-3}$. The basic density was relatively low when compared to the pine species normally used in the manufacture of particleboards, however it is an input, which has a chemical composition similar to wood. The result obtained in the present research is similar to that reported by Scatolino et al. (2013) who found $0.170 \mathrm{~g} . \mathrm{cm}^{-3}$.

The mean values shown in Table 2 refer to the levels of holocellulose, lignin, ash and corn cob extract. Corn cob is being evaluated as a raw material option for the production of panels and the results obtained for the chemical composition will 
be compared with the values in the literature for the woods traditionally used to supply industries such as pine and eucalyptus. The works by Pinati et al. (2018) for pine and Veloso et al. (2020) for eucalyptus were adopted.

Table 2. Chemical characterization of corn cob particles.

\begin{tabular}{cccc}
\hline Components & Corn cob & Pinus & Eucalyptus \\
& $(\%)$ & $(\%)$ & $(\%)$ \\
\hline Total extractives & $4.84(0.82)$ & 4.03 & 6.67 \\
Lignin & $21.87(1.07)$ & 26.08 & 27.19 \\
Ashes & $1.00(0.08)$ & 0.26 & 1.1 \\
Holocellulose & $69.49(1.75)$ & 69.63 & 65.1 \\
\hline
\end{tabular}

Values in parentheses represent the standard deviation. Source: Authors.

It is observed that the average content of the total extracts (Table 2) was similar to the content obtained for pine, but higher than that found for eucalyptus. Scatolino et al.(2013), worked with the same species and obtained an average content of $7.00 \%$, higher than that obtained in the present study. High extractive values can influence properties such as permeability and hygroscopic capacity, in addition these components can cause bursts in the pressing phase, influence the curing of the adhesive and affect the quality of bonding between the particles (Iwakiri, 2005).

The lignin content found in this research was lower than the values obtained for pine and eucalyptus. The result was superior to that reported by Scatolino et al. (2013), which obtained an average content of 14.7\%. Lignin has properties that can contribute to the adhesion process (Ang et al., 2019), promoting improvements in the quality of the panel.

The ash content was similar to that obtained for eucalyptus and lower than for pine.The value reported by Scatolino $(1.6 \%)$ was higher than that obtained in the present study. Ashes are found in minimal proportions in the material and do not directly influence the adhesion of the constituent particles of the particleboards. However, they can influence the pH and other characteristics related to the machinability and wear of cutting knives from machines, due to the presence of minerals, such as silica (Iwakiri, 2005).

The holocellulose content $(69,49 \%)$ was similar than the result found by Pinati et al.(2018) who reported a percentage value corresponding to $69.63 \%$, for this chemical fraction.The use of lignocellulosic residues is limiting because it has large amounts of holocellulose, which can negatively influence the physical properties of the panels due to the hygroscopicity, due to the free hydroxyl groups that can adhere to the water (Iwakiri et al., 2005).

\subsection{Physical properties}

The mean values for physical properties are described in Table 3. 
Table 3. Mean values of Apparent Specific Mass (MEA), Water Absorption after 2h and 24h of immersion (AA2h and AA24h) and Thickness Swelling after $2 \mathrm{~h}$ and $24 \mathrm{~h}$ (IE2h and IE24h) of the particleboards.

\begin{tabular}{|c|c|c|c|c|c|}
\hline Treatments & $\begin{array}{c}\text { MEA } \\
{\left[\mathrm{g} \cdot \mathrm{cm}^{-3}\right]}\end{array}$ & $\begin{array}{c}\text { AA2H } \\
{[\%]}\end{array}$ & $\begin{array}{c}\mathrm{AA} 24 \mathrm{H} \\
{[\%]}\end{array}$ & $\begin{array}{c}\text { IE2H } \\
{[\%]}\end{array}$ & $\begin{array}{c}\text { IE24H } \\
{[\%]}\end{array}$ \\
\hline $\mathrm{T} 1$ & 0.64 a $\mathrm{A}(0.05)$ & 50.92 a $\mathrm{A}(8.23)$ & 91.86 a A (7.39) & $21.77 \mathrm{a} A(2.07)$ & 38.63 a $\mathrm{A}(5.35)$ \\
\hline $\mathrm{T} 2$ & 0.62 a A $(0.03)$ & 54.56 a A (3.17) & 96.48 a A (3.35) & $21.73 \mathrm{~A}$ a (3.90) & 36.54 a A (2.31) \\
\hline $\mathrm{T} 3$ & $0.61 \mathrm{a} \mathrm{A}(0.04)$ & 48.06 a A (5.29) & 93.00 a $\mathrm{A}(5.96)$ & 19.19 a A (1.58) & 36.49 a $\mathrm{A}(2.66)$ \\
\hline $\mathrm{T} 5$ & 0.64 a A $(0.06)$ & 53.78 a A (4.06) & 97.26 a A (7.79) & 21.95 a A (1.82) & 37.49 a $\mathrm{A}(2.37)$ \\
\hline T6 & 0.63 a $\mathrm{A}(0.04)$ & 47.48 a A (7.44) & 92.75 a A (5.90) & $19.01 \mathrm{a} A(2.28)$ & 35.69 a $\mathrm{A}(5.01)$ \\
\hline Overall Mean & 0.63 & 50.91 & 94.00 & 20.86 & 37.07 \\
\hline
\end{tabular}

Treatments: 1) UF-6\%, 2) UF-9\%, 3) UF-12\%, 4) PF-6\%; 5) PF-9\%; 6) PF-12\%. Means followed by the same letter, in the columns, do not differ statistically by the Tukey Test $(\alpha=0.05)$. Values in parentheses represent the standard deviation. Source: Authors.

According to the data described in Table 3, it appears that the apparent specific mass of the particleboards was not influenced by the factors tested. All particleboards were classified as low density as stipulated by ANSI 208-1 (1999), which thus classifies sheets with values less than $640 \mathrm{~kg} \cdot \mathrm{m}^{-3}$. This similarity of values is important, as it excludes its effect in the comparison between treatments.

The properties of AA2h and AA24h did not show significant differences between the particleboards (Table 3). In general, the values obtained for AA2h and AA24h were similar to those reported by Scatolino et al. (2013), who worked with wood particle boards from Pinus oocarpa and corn cob, glued with $8 \%$ UF adhesive and 1\% paraffin emulsion. For particleboards made of $100 \%$ cob particles, they found approximately $47.00 \%$ for AA2h and $98.00 \%$ for AA24h.

IE is an important property to define the dimensional stability of particle boards (Iwakiri et al., 2018). Iwakiri et al. (2019) conducted an experiment with particleboards, in which they used two resins and two contents of adhesive. The researchers noted in general that the increase in content from $10 \%$ to $12 \%$ improved the dimensional stability properties of the particleboards. According to the authors, the results could have come from the greater coating and waterproofing of particles with resin, contributing to reduce the reduction in AA and, consequently, in IE.

The results obtained in this study were superior to those reported in the literature. Akinyem et al. (2016) conducted a study with corn cob particles and sawdust from particleboards using UF-based adhesive. The particleboards were produced using $0 \%, 25 \%, 50 \%, 75 \%$ and $100 \%$ agricultural waste with a constant volume of adhesive (content not informed in the research). The results showed that particleboards made of $100 \%$ corn cob showed values between 11 and $12 \%$ for IE2h and IE24h.

For the properties of AA and IE, it was expected that the particleboards constituted with PF adhesive and higher contents of it, would show reductions in these properties, due to the greater resistance of this glue, in relation to the humidity conditions and for this reason it is recommended for external environments. According to Kevin et al. (2018) particle boards glued with urea-formaldehyde-based adhesive have less dimensional stability, that is, low capacity to resist water penetration, when compared to particleboards made with phenol-formaldehyde-based adhesive. However, some factors can interfere in this process, such as, particleboard density, particle size, pressing cycle parameters, use of paraffin in the manufacture of particleboards, among others.

CS 236-66 (Commercial Standard, 1968) stipulates values for thickness swelling after 24 hours, corresponding to $30 \%$ for low density particleboards, so none of the particleboards evaluated met the requirement of the referred standard. 


\subsection{Mechanical properties}

Table 4 shows significant differences between the factors tested (type and content of adhesive) for MOR and MOE. For internal adhesion there was influence only of the type of adhesive factor, and for compression there was no significant difference between the factors.

Table 4. Mean values of the Modulus of Rupture (MOR), Modulus of Elasticity (MOE), Internal Adhesion (IA) and Compression $(\mathrm{C})$ of the particleboards.

\begin{tabular}{ccccc}
\hline \multirow{2}{*}{ Treatments } & $\begin{array}{c}\text { MOR } \\
{\left[\mathrm{g} . \mathrm{cm}^{-3}\right]}\end{array}$ & $\begin{array}{c}\text { MOE } \\
{[\%]}\end{array}$ & $\begin{array}{c}\text { IA } \\
{[\%]}\end{array}$ & $\begin{array}{c}\mathrm{C} \\
{[\%]}\end{array}$ \\
\hline 1 & $7.41 \mathrm{a} \mathrm{A}(0.85)$ & $2,168 \mathrm{a} \mathrm{A}(218.12)$ & $0.21 \mathrm{a} \mathrm{A}(0.01)$ & $3.78 \mathrm{a} \mathrm{A}(0.40)$ \\
2 & $8.08 \mathrm{a} \mathrm{AB}(0.56)$ & $2,541 \mathrm{a} \mathrm{B}(540.33)$ & $0.21 \mathrm{a} \mathrm{A}(0.01)$ & $3.37 \mathrm{a} \mathrm{A}(0.65)$ \\
\hline
\end{tabular}

Means followed by the same letter do not differ statistically by the Tukey Test $(\alpha=0.05)$. The lower case letters in the columns refer to the types of adhesive and the upper case letters in the lines refer to the adhesive contents. Source: Authors.

The results of the Tukey means test performed for the MOR variable of the interaction between the content and type of adhesive factors are shown in Table 5.

Table 5. Test of means for the variable MOR of the interaction between type and content of adhesive factors.

\begin{tabular}{cccc}
\hline \multirow{2}{*}{ Type of adhesive } & \multicolumn{3}{c}{ Adhesive contents } \\
\cline { 2 - 4 } & $6 \%$ & $9 \%$ & $12 \%$ \\
\hline UF & $7.41 \mathrm{a} \mathrm{A}$ & $8.08 \mathrm{a} \mathrm{AB}$ & $12.58 \mathrm{~b} \mathrm{~B}$ \\
PF & $12.16 \mathrm{~b} \mathrm{~B}$ & $13.14 \mathrm{~b} \mathrm{~B}$ & $15.72 \mathrm{~b} \mathrm{~B}$ \\
\hline
\end{tabular}

Means followed by the same letter do not differ statistically by the Tukey Test $(\alpha=0.05)$. The lower case letters in the columns refer to the types of adhesive and the upper case letters in the lines refer to the adhesive contents. Source: Authors.

Considering the type of adhesive factor, it appears that there was a significant difference for particleboards made of 6 and $9 \%$ contents, but there was no difference between particleboards made of glued particles with a content of $12 \%$ of adhesive. This result may be an indication that the higher adhesive content (UF or PF), provided better covering of the particles and reduced the empty spaces in the sheets, resulting in greater resistance when applying force and, consequently, reaching the best means.

When analyzing the adhesive content factor (Table 5), it can be seen that there was a significant difference in the values. For particleboards constituted with UF-based adhesive, it is observed that those with particles glued with $6 \%$ of adhesive differed from particleboards with $12 \%$ of adhesive and particleboards constituted with $9 \%$ showed intermediate behavior between them. The particleboards produced with particles glued with adhesive based on PF, did not differ among themselves, due to the better adhesive properties of the resin.

The results of the Tukey means test performed for the variable MOE of the interaction between the factors evaluated are shown in Table 6. 
Table 6. Test of means for the variable MOE of the interaction between type and content of adhesive factors

\begin{tabular}{cccc}
\hline \multirow{2}{*}{ Type of adhesive } & \multicolumn{3}{c}{ Adhesive contents } \\
\cline { 2 - 4 } & $6 \%$ & $9 \%$ & $12 \%$ \\
\hline UF & $2.168 \mathrm{a} \mathrm{A}$ & $3.54 \mathrm{~b} \mathrm{~B}$ & $4.250 \mathrm{~b} \mathrm{~B}$ \\
PF & $2.244 \mathrm{a} \mathrm{A}$ & $4.590 \mathrm{~b} \mathrm{~B}$ & $5.360 \mathrm{~b} \mathrm{~B}$ \\
\hline
\end{tabular}

Means followed by the same letter do not differ statistically by the Tukey Test $(\alpha=0.05)$. The lower case letters in the columns refer to the types of adhesive and the upper case letters in the lines refer to the adhesive content factor. Source: Authors.

In relation to Table 6, it is noted that the particleboards did not differ in relation to the types of adhesive, thus, there was statistical equivalence for all treatments evaluated (Table 6). Considering the adhesive content factor, it is noted that the treatment composed of particleboards made up of $6 \%$ adhesive content, differed from the others and showed a lower mean. However, when the adhesive content of the particleboards is increased, the resistance also increases, so that these particleboards become statistically equivalent ( 9 and 12\%). As previously mentioned, the use of higher levels of adhesive gives greater resistance to the particleboards.

Tay et al. (2016) conducted an experiment with low density particleboards with sago particles and used UF and PF in

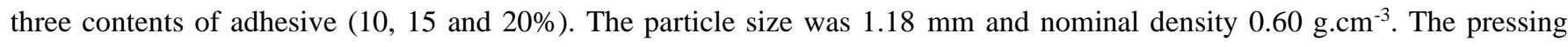
parameters were: 40 bar of pressure, temperature of $160{ }^{\circ} \mathrm{C}$ for $4 \mathrm{~min}$. The authors observed that the MOR of the particleboards with UF increased with the adhesive content (10 to 15\%), but decreased with the content of $20 \%$. The MOR values of particleboards manufactured with PF were higher than the values of particleboards produced with UF. MOR values were reduced when levels of 15 and $20 \%$ were applied.

According to the authors, the PF adhesive provides a better mechanical interlocking between the particles, easily penetrating the empty spaces of the particleboards and filling the pores of the substrate, providing good bonding, ensuring greater resistance when applying force. The values for particleboards glued with UF were higher, in relation to the PF for the MOE.

Silva et al. (2018) studied particleboards of castor bean peel. The particleboards were produced with five different levels of peel content $(0,25,50,75$ and $100 \%)$ in association with pine. The researchers used UF adhesive content at $8 \%$ and $1 \%$ paraffin. The pressing parameters were: pressure of $3.92 \mathrm{MPa}$, temperature of $160{ }^{\circ} \mathrm{C}$ and pressing time corresponding to 8 min. For low-density pine particleboards, the authors obtained 17.8 MPa and 2,783.1 MPa, for MOR and MOE, respectively, results similar to those obtained in this study.

The values obtained for MOR were similar to those found by Guimarães et al. (2019), who worked with waste particleboards and the MOE values, were higher. The researchers evaluated the effect of replacing wood with soybean hulls $\left(\right.$ density $=0.20{\mathrm{~g} . \mathrm{cm}^{-3}}^{-3}$ on particleboards produced with low density $\left(0.60 \mathrm{~g} . \mathrm{cm}^{-3}\right)$. Five percentages of particle mixture were adopted: $0,25,50,75$ and $100 \%$ of soybean and eucalyptus bark. Adhesive content corresponding to $12 \%$ based on ureaformaldehyde was used. The parameters of the pressing cycle were: pressure of $4.0 \mathrm{MPa}$, temperature of $180^{\circ} \mathrm{C}$ for $15 \mathrm{~min}$. For particleboards with $100 \%$ soy residue, the authors obtained values for MOR and MOE between 10 and $15 \mathrm{MPa}$ and 1,111 MPa, respectively. Scatolino et al. (2013) found mean values of MOE of $220 \mathrm{MPa}$ for particleboards made with $100 \%$ corn cob and $8 \%$ UF adhesive, lower than those obtained in this study.

According to ANSI A208.1 - 1999, the minimum value required for MOR is $3 \mathrm{MPa}$, for low density particleboards. Therefore, all particleboards produced showed values higher than the minimum stipulated by the aforementioned standard. Also according to the same standard, in relation to the MOE, all particleboards reached values above $550 \mathrm{MPa}$, which is the minimum specified value, and thus all particleboards produced with corncob, meet this requirement. 
The result of the Tukey means test for the IA of the adhesive type factor is shown in Table 7.

Table 7. Test of means for the variable internal adhesion according to the type of adhesive factor.

\begin{tabular}{cc}
\hline Type of adhesive & Internal adhesion [Mpa] \\
\hline UF & $0.21 \mathrm{a}$ \\
PF & $0.53 \mathrm{~b}$ \\
\hline
\end{tabular}

Means followed by the same letter, in the column, do not differ statistically by the Tukey Test $(\alpha=0.05)$. Source: Authors.

For the internal adhesion variable, there was a significant difference only for the type of adhesive factor (Table 7). It is observed that the particleboards made with PF adhesive showed a higher mean value and, therefore, obtained the best performance, thus demonstrating a better bonding quality and adhesion between the particles.

The mean value obtained for particleboards made up of UF was lower than that found by Scatolino et al. (2013), who obtained 0.25 MPa for internal adhesion on particleboards made with 8\% UF adhesive. Silva et al. (2018) found a value of 1.08 MPa for internal adhesion, for low density pine particleboards. The particleboards produced in this research met the minimum internal adhesion value of ANSI A208.1 - 1999, which is 0.10 MPa, for low density particleboards.

Also according to Table 4, it is observed that the particleboards did not show any significant difference for the evaluated factors, in relation to the compression test. However, there is a trend towards greater resistance of particleboards produced with PF adhesive. The values obtained were close to those found by Mendes et al. (2014) who worked with particleboards of Pinus oocarpaand clones of Eucalyptus urophylla. They used UF-based adhesive with a content of $6 \%$ and nominal density of $0.60 \mathrm{~g} . \mathrm{cm}^{-3}$. The pressing parameters were: pressure of $40 \mathrm{kgf} . \mathrm{cm}^{-2}$, temperature of $160{ }^{\circ} \mathrm{C}$ and time of 8 min. They obtained mean values of 3.8 and 3.3 MPa for particleboards produced with pine and eucalyptus clones, respectively.

\section{Conclusion}

The corn cob showed similar contents with the pine wood in relation to the extractive and holocellulose contents. All panels were classified as low density. The increase in adhesive content did not affect the physical properties of water absorption and thickness swelling after two and 24 hours of immersion in water.

All particleboards produced showed low dimensional stability and none of the treatments met the minimum requirement stipulated by ANSI A208.1, for IE24h. The type and content of the adhesive influenced the mechanical properties of MOR and MOE and all the particleboards tested met the requirements of ANSI A208.1 for low density particleboards. The IA was influenced only by the type of adhesive and showed the highest values for the PF adhesive and all particleboards met the minimum required by the standard.

It is recommended in future works to add another lignocellulosic material in the composition of the panels with a density different from corn cob and, thus, improve the compaction ratio, which may provide better results. Another improvement can be obtained by increasing the adhesive content, since the specific surface area of the corn cob particles is high. It is also recommended to apply some type of thermal or chemical treatment on the particles, in order to improve the performance of the panels. 


\section{Acknowledgments}

The authors thank the Coordination for the Improvement of Higher Education Persons (CAPES), Foundation for Research Support of the State of Minas Gerais (FAPEMIG), National Council for Scientific and Technological Development $(\mathrm{CNPq})$, the Graduate Program in Biomaterials Engineering (PPG BIOMAT-UFLA).

\section{References}

ASTM. (2020). D 1037-12: standard test methods of evaluating properties of wood-base fiber and particles materials. American Society for Testing and Materials (ASTM). West Conshohocken Pennsylvania, EUA. https://www.astm.org/Standards/D1037.htm

ANSI 208.1 (1999). ANSI 208.1: particleboard. American National Standards Institute (ANSI). Gaithersburg, Maryland, Estados Unidos. https://pt.scribd.com/doc/253309972/ANSI-A208-1-1999-PB

Ang, A. F., Ashaari, Z., Lee, S. H., Tahir, P. M. \& Halis, R (2019). Lignin-based copolymer adhesives for composite wood panels - A review. Int. J. Adhes 95: 1-12. https://doi.org/10.1016/j.ijadhadh.2019.102408

ABNT. (2003). NBR 11941: madeira: determinação da densidade básica. Associação Brasileira de Normas Técnicas (ABNT).

ABTCP (1974). Métodos de ensaio. Associação Brasileira Técnica de Celulose e Papel (ABTCP).

ABNT (2003). NBR 13999: papel, cartão, pastas celulósicas e madeira - Determinação do resíduo (cinza) após a incineração a 525C. Associação Brasileira de Normas Técnicas (ABNT). Rio de Janeiro.

CGEE. (2018). Economia do Bambu no Brasil: Tecnologia e Inovação na Cadeia Produtiva - Perspectivas e Desafios. Documento contendo o relatório técnico e analítico do seminário e da oficina de trabalho. Brasília: Centro de Gestão e Estudos Estratégicos (CGEE). https://www.cgee.org.br/document s/10195/734063/3368_Nota+T\%C3\%A9cnica+Cadeia+Produtiva+do+Bambu.pdf/2118fc55-dd2e-4a0c-994c-55525879fd2b?version=1.0

CEPEA e CNA (2020). Centro de Estudos Avançados em Economia Aplicada e Confederação Nacional da Agricultura e Pecuária. PIB do agronegócio brasileiro de 1996 a 2019. https://www.cepea.esalq.usp.br/br/pib-do-agronegocio-brasileiro.aspx

CS (1966). CS - 236: mat formed wood particle board. San Francisco, California, Estados Unidos.

CONAB (2021). Acompanhamento Da Safra Brasileira De Grãos, v. 8 - Safra 2020/21, n. 6 - Sexto Levantamento, Brasília, p. 1-106.

Cortini, E., Gazzoni, D., Adalberto, A., Mota, M. \& Marra, R. (2018). EMBRAPA. Série Desafios Do Agronegócio Brasileiro (NT2) Milho - Caracterização e Desafios Tecnológicos: EMBRAPA, 35 p.

DIN (1982). DIN 52362: testing of wood chipboards, bending test, determination of bending strength, Berlin, Alemanha. https://tienda.aenor.com/norma-din52362-1-1965-04-554492

Guimarães, I. L., Veloso, M. C. R. A., Lisboa, F. J. N., Mendes, R. F., Mendes, L. M., Farrapo, C. L., Guimarães Junior, J. B. (2019). Aproveitamento do casquilho de soja para a produção de painéis aglomerados convencionais de baixa densidade. Rev. Bras. Ciênc. Agrár 14(2): e5643. https://doi.org/10.5039/agraria.v14i2a5643.

Iwakiri, S. (2005). Painéis de madeira reconstituída. FUPEF.

Iwakiri, S., Andrade, A. S., Cardoso Júnior, A. A., Chipanski, E. R., Prata, J. G. \& Adriazola, M. K. O. Produção de painéis aglomerados de alta densificação com uso de resina melamina-ureia-formaladeído. Cerne 11(4): 323-328.

Iwakiri, S., Trianoski, R., Nascimento, C. C., Juizo, C. G. F., Lengowski, E. C., Bilcati, G. K. \& Gonçalves, T. (2018). Painéis aglomerados produzidos com seis espécies de madeiras tropicais da Amazônia. Madera y Bosques 24(3): e243371. https://doi.org/10.21829/myb.2018.243371

Iwakiri, V. T., Trianoski, R., Razera, D. L., Iwakiri, S. \& Rosa, T. S. (2019). Produção de painel aglomerado estrutural de Mimosa scabrella Benth com resina lignina-fenol-formaldeído. Floram 26(3): e20171006. http://dx.doi.org/10.1590/2179-8087.100617

Kevin, E. I., Ochanya, O. M., Olukemi, A. M., Bwanhot, S. T. N. \& Uche, I. (2018). Mechanical Properties of Urea Formaldehyde Particle Board Composite. Am. J. Chem. Eng 2(1): 10-15. http://www.sciencepublishinggroup.com/j/ajcbe

Mendes, R. F., Mendes, L. M., Mendonça, L. L., Guimarães Júnior, J. B. \& Mori, F. A. (2014). Qualidade de painéis aglomerados homogêneos produzidos com a madeira de clones de Eucalyptus urophylla. Cerne 20(2). https://doi.org/10.1590/01047760.201420021273

Oliveira, M. L., Souza, L. G. M., Pereira Neto, R. V. \& Lima, J. C. (2020). Obtenção e caracterização de um compósito com matriz de resina poliéster e carga de resíduos do sabugo de milho. Res., Soc. Dev 9(12): e32791210849. http://dx.doi.org/10.33448/rsd-v9i12.10849

Pinati, E., Faria, D. L., Mendes, R. F., Mendes, L. M., Protásio, T. P. \& Guimarães Júnior, J. B. (2018). Painéis compensados sarrafeados produzidos com Pinus oocarpa, Castilla uleie Acrocarpus fraxinifolius. Ci. Madeira 9(3): 199-208. http://dx.doi.org/10.12953/2177-6830/rcm.v9n3p199-208x

Scatolino, M. V., Silva, D. W., Mendes, R. F. \& Mendes, L. M. (2013). Use of maize cob for production of particleboard. Ciênc. e Agrotecnologia 37(4): 330 337. https://doi.org/10.1590/S1413-70542013000400006 
Research, Society and Development, v. 10, n. 11, e541101119828, 2021

(CC BY 4.0) | ISSN 2525-3409 | DOI: http://dx.doi.org/10.33448/rsd-v10i11.19828

Silva, D. W., Farrapo, C. L., Pereira, D., Mendes, R. F. \& Mendes, L. M. (2015). MDP com partículas de eucalipto e palha de milho. Sci For 43(108): 853862. https://doi.org/10.18671/scifor.v43n108.10

Silva, D. W., Scatolino, M. V., Prado, N. R. T., Mendes, R. F. \& Mendes, L. M. (2018). Addition of Different Proportions of Castor Husk and Pine Wood in Particleboards. Waste and Biomass Valorization 9: 139 - 145. https://doi.org/10.1007/s12649-016-9742-7

Tay, C. C., Hamdan, S. \& Osman, M. S. B. Properties of Sago Particleboards Resinated with UF and PF Resin. (2016). Adv. Mater. Sci. Eng 11: 1-12. https://doi.org/10.1155/2016/5323890

Veloso, M. C. R. A., Lopes, F. M., Furtini, A. C. C., Silva, M. G., Mendes, L. M. \& Guimarães Júnior, J. B. (2020). Low Density particleboard properties produced with jupati particles and eucalyptus wood. Rev Bras Ciênci Agrár 15(4): e8414. http://www.agraria.pro.br/ojs32/index.php/RBCA/article/view/v15i4a8414 